\title{
Sclerotinia Blight Resistance in Virginia-Type Peanut Transformed with a Barley Oxalate Oxidase Gene
}

\author{
D. E. Partridge-Telenko, J. Hu, D. M. Livingstone, B. B. Shew, P. M. Phipps, and E. A. Grabau
}

First and fifth authors: Virginia Tech, Tidewater Agricultural Research \& Extension Center, Suffolk 23437; second author: Department of Plant Pathology, University of Florida, Gainesville 32611; third author: 9 Scott's Camp Road, Pozieres, Queensland 4352, Australia; fourth author: Department of Plant Pathology, North Carolina State University, Raleigh 27695; and sixth author: Department of Plant Pathology, Physiology \& Weed Science, Virginia Polytechnic Institute \& State University, Blacksburg 24061.

Accepted for publication 29 January 2011

\begin{abstract}
Partridge-Telenko, D. E., Hu, J., Livingstone, D. M., Shew, B. B., Phipps, P. M., and Grabau, E. A. 2011. Sclerotinia blight resistance in Virginiatype peanut transformed with a barley oxalate oxidase gene. Phytopathology 101:786-793.

Transgenic peanut lines expressing oxalate oxidase, a novel enzyme to peanut, were evaluated for resistance to Sclerotinia blight in naturally infested fields over a 5-year period. Area under the disease progress curve (AUDPC) for transgenic lines in single rows planted with seed from single-plant selections averaged 78,83 , and $90 \%$ lower than nontrans-

in 16 transgenic lines in 2006. Six transgenic lines yielded 488 to $1,260 \mathrm{~kg} / \mathrm{ha}$ greater than nontransgenic parents in 2005, and 10 lines yielded 537 to $2,490 \mathrm{~kg} / \mathrm{ha}$ greater in 2006 . Fluazinam ( $0.58 \mathrm{~kg}$ a.i./ha) fungicide sprays in 2008 and 2009 reduced AUDPC in transgenic and nontransgenic lines but AUDPC was lowest in transgenic lines. Without fluazinam, yields of transgenic lines averaged 1,133 to $1,578 \mathrm{~kg} / \mathrm{ha}$ greater than nontransgenic lines in 2008 and 1,670 to $2,755 \mathrm{~kg} / \mathrm{ha}$ greater in 2009. These results demonstrated that the insertion of barley oxalate oxidase in peanut conveyed a high level of resistance to Sclerotinia blight, and negated the need for costly fungicide sprays.
\end{abstract} genic parents in 2004, 2005, and 2006, respectively. In addition, AUDPC in 14 transgenic lines planted with bulked seed in two-row plots averaged $81 \%$ lower compared with nontransgenic parents in 2005 and $86 \%$ lower
Additional keywords: Arachis hypogaea, disease resistance, oxalic acid, Sclerotinia minor.
Sclerotinia blight, caused by the soilborne fungus Sclerotinia minor Jagger, is a major disease of peanut (Arachis hypogaea L.) in the United States. The disease was first found in Virginia and northeastern North Carolina $(2,21)$ and subsequently in parts of Texas (30), Oklahoma (26), and New Mexico (25). During favorable conditions for Sclerotinia blight (19), yield losses can reach $57 \%$ (24). Production of oxalic acid by S. minor, S. sclerotiorum, and Sclerotium rolfsii is thought to be a pathogenicity factor that predisposes plants to infection and disease $(1,7,8)$. Oxalate oxidase is an enzyme that degrades oxalic acid to produce carbon dioxide and hydrogen peroxide and prevents the predisposition of cells to infection by oxalic acid-producing fungi (29). Barley oxalate oxidase shows a high degree of homology to wheat germin, a protein in wheat that is expressed during germination (12). Similar proteins with oxalate oxidase activity are naturally found in cereals such as corn, wheat, barley, rye, oat, sorghum, and rice $(4,6,22,29)$. Oxalate oxidase is upregulated in wheat and barley in response to pathogen attack by powdery mildew $(10,31)$.

The oxalate oxidase gene is thought to enable plant cells to destroy oxalic acid and slow or prevent disease development. The release of hydrogen peroxide catalyzed by the oxalate oxidase protein may also trigger cross linking of plant cell wall proteins in papillae at the site of infection (28) and plant hypersensitive responses $(11,32)$ that would prevent fungal infection. Oxalate oxidase gene has been successfully inserted into Virginia-type peanut and shown in growth-chamber studies to enhance resistance to Sclerotinia blight through degradation of oxalic acid (17).

Corresponding author: P. M. Phipps; E-mail address: pmphipps@vt.edu

doi:10.1094/PHYTO-10-10-0266

(c) 2011 The American Phytopathological Society
Field indices of available moisture in the form of rainfall or humidity $>95 \%$, air or soil temperatures $<29^{\circ} \mathrm{C}$, vine growth, and density of foliar canopy are used for predicting outbreaks of Sclerotinia blight $(13,19)$ and the need for fungicide sprays. Although this approach has improved the efficiency of fungicide applications in disease control, it has not reduced the need for fungicide sprays. Furthermore, commercial cultivars of Virginiaand runner-type peanut exhibit some differences in susceptibility to Sclerotinia blight $(18,20)$ but none have allowed a reduction in the need for fungicide sprays.

The high cost of crop production and reduced value of peanut since the 2002 Farm Bill have forced many growers in the Virginia-North Carolina region to stop growing peanut. Losses of yield to Sclerotinia blight and the need for two or three fungicide sprays of fluazinam (Omega 500; ISK BioSciences) costing \$208 to 312 ha were among the important factors accounting for production in Virginia falling from 23,473 ha in 2002 to 6,880 ha in 2006. The importance and impact of Sclerotinia blight on peanut production in the Virginia-Carolina region served as the rationale for employing a biotechnology approach to improving disease resistance.

The current study characterized disease resistance and yield of transgenic lines of Virginia-type peanut enhanced with a barley oxalate oxidase gene. The primary goal was to evaluate the effectiveness of this novel enzyme in peanut in providing resistance under natural disease conditions in the field and define yield advantages of transgenic lines compared with their corresponding nontransgenic parents.

\section{MATERIALS AND METHODS}

Origin of transgenic lines. Transgenic peanut lines were generated from three Virginia-type cultivars (NC 7, Perry, and 
Wilson) by introduction of a cloned barley oxalate oxidase gene. The barley oxalate oxidase cDNA was amplified from total barley RNA using upstream primer 5'GCAAGGTACCATGGGTTA CTCTAAAAACCTAG and downstream primer 5'GCAAGTC GACTGGGGCTCATGGAAGTTAAG designed from the reported sequence (accession no. Y14203) (32). The resulting product was inserted as a KpnI-SalI fragment (sites in primers underlined above) under transcriptional control of the dual-enhanced Cauliflower mosaic virus promoter into a transformation vector (14) to yield pOxOx. Embryogenic cultures were initiated and maintained according to the method of Livingstone and Birch (16). Microprojectile bombardment with the gene gun was used for transformation (Bio-Rad, Hercules, CA). Plantlets were regenerated as described by Livingstone et al. (17) following selection on hygromycin for transformed callus. After transfer of plantlets to soil, growth conditions included daylight plus supplemental light (sodium halide and high-intensity discharge lighting) for $12 \mathrm{~h}$ a day. Seed were produced and harvested from transgenic plants ( $T_{0}$ generation) in the greenhouse in 2003 and $T_{1}$ seed of superior lines were planted in the greenhouse for seed increase during winter 2003-04. After confirming the presence of the oxalate oxidase gene and expression of enzyme activity in detached leaflet assays, $\mathrm{T}_{2}$ seed were harvested from transgenic plants with acceptable agronomic traits for field trials.

Field trials. Each year, the Animal and Plant Health Inspection Service (APHIS) approved testing of the $\mathrm{T}_{2}$ to $\mathrm{T}_{9}$ generations of transgenic lines at the Virginia Tech Tidewater Agricultural Research and Extension Center (TAREC) in Suffolk, VA in 2004 to 2009. Disease intensity from Sclerotinia blight at TAREC was generally moderate to high each year, except for 2007, when above-normal temperatures and below-normal rainfall limited disease development to low levels in all plots. In addition, APHIS granted approval for field trials of the $\mathrm{T}_{5}$ and $\mathrm{T}_{6}$ generations in 2007 and 2008 at the Upper Coastal Plain Research Station (UCPRS) in Rocky Mount, NC. Unfortunately, the trials at UCPRS were inconclusive in demonstrating disease resistance or susceptibility to Sclerotinia blight in transgenic and nontransgenic parents due to low and nonuniform disease intensity. Therefore, the results for trials at TAREC in 2007 and at UCPRS in 2007 and 2008 are not presented.

Field trials at TAREC were Kenansville loamy sand with a history of cotton-peanut rotation prior to 2004 and a cotton-cornpeanut rotation in 2005 to 2009. Metam sodium 42\% (Vapam HL; AMVAC Chem. Corp., Los Angeles) at $35.8 \mathrm{~kg}$ a.i./ha was applied either once or twice at $20.3 \mathrm{~cm}$ under rows and at least 2 weeks prior to planting each year for control of Cylindrocladium black rot (CBR) and nematodes. Disks and a bed shaper produced smooth beds measuring $61 \mathrm{~cm}$ wide and $10.2 \mathrm{~cm}$ high over treated rows. Standard practices for production of Virginiatype peanut were followed during each growing season.

Rainfall at TAREC in May to October totaled $109.4 \mathrm{~cm}$ (39.1 cm above normal) in 2004, $65.7 \mathrm{~cm}$ (4.5 cm below normal) in $2005,92.5 \mathrm{~cm}(21.9 \mathrm{~cm}$ above normal $)$ in $2006,44.6 \mathrm{~cm}$ (25.9 cm below normal) in $2007,49.9 \mathrm{~cm}$ (20.6 cm below normal) in 2008, and $65.2 \mathrm{~cm}$ (4.8 cm below normal) in 2009. Overhead irrigation was applied at TAREC during periods of drought stress for a total of $10.7 \mathrm{~cm}$ in $2005,5.7 \mathrm{~cm}$ in $2006,14.6 \mathrm{~cm}$ in 2007, $7.6 \mathrm{~cm}$ in 2008, and $7.6 \mathrm{~cm}$ in 2009.

Transgenic seed from single-plant selections and certified seed of nontransgenic parent cultivars (NC 7, Wilson, and Perry) were hand planted $15.2 \mathrm{~cm}$ apart (to allow for single-plant selections) in single-row plots of 15,20 , or 25 seeds/row according to seed availability in 2004, 50 plants/row in 2005, and 40 plants/row in 2006. $\mathrm{T}_{2}$ seed from 56 single-plant selections were pregerminated in paper towels saturated with water and ethephon at $0.173 \mathrm{~g}$ a.i./ liter (Cerone Brand-4 Plant Regulator; Bayer CropScience, Research Triangle Park, NC) prior to planting in the field on 9 June 2004. The treatment was required to break seed dormancy be- cause seed were harvested from the greenhouse just prior to planting in the field. Thereafter, the treatment was not needed because seed were harvested from field plantings the previous year and placed in cold storage. $T_{3}$ seed from 20 single-plant selections were planted on 1 June 2005, and $\mathrm{T}_{4}$ seed from 22 single-plant selections were planted on 3 May 2006, along with their nontransgenic parents. In all 3 years, rows were spaced 0.9 $\mathrm{m}$ apart. Each year, single-plant and bulk selections of plants from superior lines were made based on oxalate oxidase expression, disease resistance, and yield. Seed harvested from these plants were used to plant field trials in subsequent years. Plants were dug on 27 October 2004, 1 November 2005, and 19 October 2006 and harvested on 1 and 2 November 2004, 9 November 2005, and 2 November 2006. Yield was determined after drying and adjusting the weight of whole pods to $7 \%$ moisture.

Bulked $\mathrm{T}_{3}$ to $\mathrm{T}_{7}$ seed were harvested from field plots in 2004 to 2008 and planted in replicated field trials in 2005 to 2009 for comparing disease resistance and yield in transgenic lines and nontransgenic parent cultivars. Transgenic lines and their parents were replicated in four randomized complete blocks in plots composed of two rows spaced $0.9 \mathrm{~m}$ apart and $7.6 \mathrm{~m}$ long in 2005 and $9.1 \mathrm{~m}$ long annually in 2006 to 2009. Trials at TAREC with bulked seed were planted on 31 May 2005, 2 May 2006, 14 May 2007, 8 May 2008, and 12 May 2009 at a rate of $9.8 \mathrm{seed} / \mathrm{m}$ of row with KMC planters (Kelly Manufacturing Company, Tifton, GA). These trials were harvested on 1 November 2005, 31 October 2006, 2 November 2007, 16 October 2008, and 26 October 2009.

Response to fungicide treatment. Field trials comparing the response of transgenic lines and their nontransgenic parents to fungicide treatments for control of Sclerotinia blight were conducted at TAREC in 2007, 2008, and 2009. The experimental design was a split-plot with fungicide treatment in main plots and subplots of transgenic lines and their nontransgenic parents. The commercial standard treatment with fluazinam at $0.58 \mathrm{~kg}$ a.i./ha (Omega 500; Syngenta Crop Protection, Research Triangle Park, Raleigh, NC) was applied by a tractor-mounted sprayer according to weather-based Sclerotinia blight advisories (13) that were issued daily during each growing season. The sprayer was equipped with three disc-core combination $\left(\mathrm{D}_{3} 23\right)$ nozzles per row and delivered a spray volume of 140 liters/ha. Chlorothalonil at $1.26 \mathrm{~kg}$ a.i./ha (Bravo Weather Stik; Syngenta Crop Protection) was applied for control of early leaf spot and other foliar diseases according to daily leaf-spot advisories in all trials. No other fungicides were applied.

Enzyme activity assay. Oxalate oxidase enzyme activity in transgenic plants was determined using a colorimetric method $(10,17)$ to detect hydrogen peroxide released from degradation of oxalic acid. Leaf discs $(0.5 \mathrm{~cm}$ in diameter $)$ were placed in individual wells of a microtiter plate with $200 \mu \mathrm{l}$ of assay buffer containing $180 \mu \mathrm{g}$ of oxalic acid (Fisher Chemicals, Fairlawn, NJ) in $2.5 \mathrm{mM}$ succinic acid solution (Fisher Chemicals) at $\mathrm{pH} 3.5$ and incubated for $25 \mathrm{~min}$ at $37^{\circ} \mathrm{C}$. After incubation, $100 \mu \mathrm{l}$ of the solution from each reaction was transferred to a new 96-well plate and $70 \mu \mathrm{l}$ of developing solution $(6 \mathrm{mg}$ of aminoantipyrene [Sigma-Aldrich, St. Louis] plus $30 \mu \mathrm{l}$ of N,N-dimethylaniline [ACROS Organics, Morris Plains, NJ] dissolved in $100 \mathrm{ml}$ of $0.1 \mathrm{M}$ sodium phosphate buffer at $\mathrm{pH} 7.0$ with $57 \mu$ of a solution of horseradish peroxidase EC 1.11.1.7 at $140 \mathrm{mg} \mathrm{ml}^{-1}$ [SigmaAldrich]) was added to each well. A purple color developed to indicate the presence of the hydrogen peroxide product. The reaction was allowed to continue for $25 \mathrm{~min}$ at room temperature, at which time absorbance was measured at a wavelength of $562 \mathrm{~nm}$ by a microplate reader EL311 (Bio-Tek Instruments, Inc., Winooski, VT) in trials in 2004 to 2008. In 2009, absorbance was measured at $550 \mathrm{~nm}$ by a microplate reader EL800 (Bio-Tek Instruments). All plants were sampled from each of the handplanted trials and 10 plants were flagged arbitrarily and sampled in each two-row plot of replicated trials in 2006 to 2009. 
Oxalic acid bioassay. Leaflets were taken from the fullyexpanded leaf near the tip of the mainstem on each plant in handplanted trials in 2005 and 2006. The detached leaflets were arranged in humid boxes containing wet paper towels. Each leaflet was wounded in four locations with an 18-gauge needle on the abaxial surface. A $15-\mu$ droplet of $100 \mathrm{mM}$ oxalic acid (Fisher Chemicals) was applied to each wound. Leaflets were incubated for $6 \mathrm{~h}$ at room temperature $\left(25^{\circ} \mathrm{C}\right)$ and leaves were rinsed and photographed under a stereo microscope (Nikon SM2645, Tokyo). The number of pixels per lesion was quantified from the digital image using Adobe Photoshop 7.0 (Adobe Systems Incorporated, San Jose, CA) and converted to area in square millimeters.

Disease assessment. Disease severity in 2004, 2005, and 2006 was scored on a plant-by-plant basis in small plots on a scale from 0 to 3 , where $0=$ none, $1=\leq 10 \%$ of limbs with disease, $2=$ 11 to $50 \%$ of limbs with disease, and $3=51$ to $100 \%$ of limbs with disease. In addition, three to five counts of disease incidence were obtained in field trials with large plots in 2005 to 2009 at 2- or 3-week intervals, with the first at initial disease onset and the final just prior to harvest. Incidence of Sclerotinia blight was determined by counting the number of infection centers with signs of Sclerotinia minor or symptoms of Sclerotinia blight in each two-row plot or a total of $15.2 \mathrm{~m}$ of row in 2005 and $18.3 \mathrm{~m}$ of row in 2006, 2007, 2008, and 2009. An infection center was a point of active growth by $S$. minor and included $15.2 \mathrm{~cm}$ on either side of that point. Area under the disease progress curve (AUDPC) was calculated to compare disease intensity in parent cultivars and transgenic lines (23). Occurrences of other diseases in field plots were recorded based on symptoms and signs in field trials.

Data analysis. Data from single-plant selections were combined for each original transformation event $\left(T_{0}\right)$ and tested for statistical significance from nontransgenic parents by $t$ test. A randomized complete block design was used in trials planted to bulked seed in two-row plots in 2005 and 2006. Analysis of variance (ANOVA) (version 9.1; SAS Institute Inc., Cary, NC) and Fisher's protected least significant difference (LSD) were used to compare transgenic lines and their nontransgenic parents. In 2008 and 2009, the experimental design was a split-plot with and without fluazinam fungicide treatment in main plots and subplots of transgenic lines and their nontransgenic parents in four randomized complete blocks. Significant interactions between fungicide treatments (treated versus untreated) and lines (transgenic and nontransgenic) were detected in both years. Therefore, the data analysis used ANOVA and Fisher's protected LSD at $P \leq 0.05$ to detect differences in lines within main plots (fluazinam-treated and nontreated).

\section{RESULTS}

Trials with seed from single-plant selections. In 2004, $\mathrm{T}_{2}$ seed from $56 \mathrm{~T}_{1}$ single-plant selections representing 13 original transformation events $\left(\mathrm{T}_{0}\right)$ were planted along with nontransgenic parent cultivars in a field naturally infested with $S$. minor. Oxalate oxidase expression in 21 of the 56 transgenic lines from singleplant selections in the $T_{2}$ generation showed oxalate oxidase gene expression $\geq 0.065$ absorbance, which was adopted as the threshold for transformed plants in colorimetric assays for hydrogen peroxide production (data for individual lines not shown). When grouped according to the original transformation event $\left(\mathrm{T}_{0}\right), 9$ of the 13 original transformation events showed oxalate oxidase expression that averaged $\geq 0.065$ absorbance and 7 were significantly different from the corresponding nontransgenic parents (Table 1). Three lines of transformed Perry appeared to be segregating for the oxalate oxidase transgene in the $\mathrm{T}_{2}$ generation because some plants in each row showed no oxalate oxidase expression. Sclerotinia blight severity was reduced in all 13 transgenic lines compared with their nontransgenic parents. In 2004, transgenic lines had an average of 77, 75, and $80 \%$ lower disease severity compared with their corresponding nontransgenic parents NC 7, Perry, or Wilson, respectively.

In 2005, $\mathrm{T}_{3}$ seed from $20 \mathrm{~T}_{2}$ single-plant selections representing 10 original $\mathrm{T}_{0}$ transformation events were planted. Of the 20 transgenic lines in the $\mathrm{T}_{3}$ generation, 19 showed strong oxalate oxidase expression $(\geq 0.065)$ according to the colorimetric assay (data not shown). When grouped according to their $\mathrm{T}_{0}$ parent, 9 of the 10 lines showed significant oxalate oxidase expression (Table 1). All 10 transformation events had reduced severity of Sclero-

TABLE 1. Oxalate oxidase expression (Oxox), Sclerotinia blight severity, and oxalic acid (OA) sensitivity in transgenic lines from individual plant selections hand-planted in field trials in 2004, 2005, and $2006^{\mathrm{z}}$

\begin{tabular}{|c|c|c|c|c|c|c|c|c|c|c|c|}
\hline \multirow[b]{2}{*}{ Line $\left(\mathrm{T}_{0}\right)$} & \multicolumn{3}{|c|}{$\mathrm{T}_{2}(2004)$} & \multicolumn{4}{|c|}{$\mathrm{T}_{3}(2005)$} & \multicolumn{4}{|c|}{$\mathrm{T}_{4}(2006)$} \\
\hline & $\mathrm{N}$ & Oxox & Sev & $\mathrm{N}$ & Oxox & $\mathrm{Sev}$ & OA lesion & $\mathrm{N}$ & Oxox & Sev & OA lesion \\
\hline NC7 (nontransgenic) & 3 & -0.008 & 1.74 & 1 & -0.006 & 1.02 & 6.70 & 1 & 0.018 & 1.44 & 8.94 \\
\hline Perry (nontransgenic) & 9 & 0.015 & 0.98 & 1 & -0.008 & 0.84 & 6.28 & 1 & 0.021 & 0.97 & 7.81 \\
\hline P99 & 4 & 0.093 & $0.41 * * * *$ & 3 & $0.323 * * * *$ & $0.01 * * * *$ & $1.64 * * * *$ & 6 & $0.613 * * * *$ & $0.05 * * * *$ & $2.21 * * * *$ \\
\hline P39 & 2 & 0.086 & $0.03 * * * *$ & 1 & $0.304 * * * *$ & $0.02 * * * *$ & $1.72 * * * *$ & 2 & $0.700 * * * *$ & $0.02 * * * *$ & $2.06 * * * *$ \\
\hline Wilson (nontransgenic) & 9 & -0.007 & 1.54 & 1 & -0.005 & 1.02 & 7.06 & 1 & 0.018 & 2.19 & 8.86 \\
\hline W14 & 3 & $0.053^{*}$ & $0.24 * * * *$ & 2 & $0.163 * * * *$ & $0.00 * * * *$ & $2.66 * * * *$ & 2 & $0.260 * * * *$ & $0.14 * * * *$ & $4.23 * * * *$ \\
\hline W171 & 9 & $0.074 * * *$ & $0.35 * * * *$ & 2 & $0.311 * * * *$ & $0.28 * * * *$ & $3.59 * * * *$ & 2 & $0.162 * * * *$ & $0.42 * * * *$ & $3.78 * * * *$ \\
\hline W59 & 5 & $0.077 * * *$ & $0.32 * * * *$ & 3 & 0.160 **** & $0.31 * * * *$ & $3.98 * * * *$ & 2 & $0.181 * * * *$ & $0.18 * * * *$ & $5.26 * * * *$ \\
\hline W73 & 9 & $0.074 * * *$ & $0.23 * * * *$ & 1 & $0.266 * * * *$ & $0.50 * * *$ & $3.45 * * * *$ & $\ldots$ & - & - & - \\
\hline W83 & 4 & $0.102 * * * *$ & $0.34 * * * *$ & 1 & 0.062 & $0.22 * * * *$ & $3.32 * * * *$ & $\ldots$ & - & - & - \\
\hline W147 & 1 & 0.032 & $0.00 * * * *$ & $\ldots$ & - & - & - & $\ldots$ & - & - & - \\
\hline
\end{tabular}

${ }^{\mathrm{z}}$ Significant differences in nontransgenic parent and its transgenic lines were determined by a $t$ test, where $*, * *, * * *$, and $* * * *$ denote significance at $P=0.05$, $0.01,0.001$, and 0.0001 , respectively; - indicates lines not tested in 2005 or 2006. $N=$ number of single-plant selections from each original transformation and rows of nontransgenic parent evaluated in the field, with data pooled according to nontransformed parent or original transformation $\left(\mathrm{T}_{0}=\right.$ parent or original transformed plant with oxalate oxidase gene, $\mathrm{T}_{2}=$ second generation, $\mathrm{T}_{3}=$ third generation, and $\mathrm{T}_{4}=$ fourth generation). Average Oxox determined from leaflet samples taken in September of each year using a colorimetric detection method. Sev $=$ disease severity rated on a scale of 0 to 3 for each plant, where $0=$ no disease, $1=\leq 10 \%$ limbs with disease, $2=11$ to $50 \%$ of limbs with disease, and $3=51$ to $100 \%$ of limbs with disease on 13 October 2004,26 October 2005 , and 12 October 2006. OA lesion $=$ detached leaflets were wounded with 18-gauge needle on abaxial side and a $15 \mu \mathrm{l}$ droplet of $100 \mathrm{mM}$ OA was applied to each wound. The number of pixels within each lesion was converted to square millimeters. 
TABLE 2. Oxalate oxidase expression (Oxox), Sclerotinia blight severity, and incidence for nontransgenic parent and $19 \mathrm{~T}_{3}$ transgenic lines in $2005^{\mathrm{v}}$

\begin{tabular}{|c|c|c|c|c|c|c|}
\hline \multirow[b]{2}{*}{ Line $\left(\mathrm{T}_{0}-\mathrm{T}_{1}-\mathrm{T}_{2}\right)^{\mathrm{w}}$} & \multirow{2}{*}{$\begin{array}{c}\text { Oxох }^{\mathrm{x}} \\
29 \text { September }\end{array}$} & \multicolumn{2}{|c|}{ Sclerotinia blight severity ${ }^{\mathrm{y}}$} & \multicolumn{3}{|c|}{ Sclerotinia blight incidence ${ }^{\mathrm{z}}$} \\
\hline & & 4 October & 27 October & 9 September & 4 October & 27 October \\
\hline NC7 (nontransgenic) & $-0.008 \mathrm{c}$ & $1.13 \mathrm{a}$ & $2.35 \mathrm{a}$ & $9.3 \mathrm{a}$ & $33.0 \mathrm{a}$ & $35.8 \mathrm{a}$ \\
\hline N99-4-B & $0.405 \mathrm{a}$ & $0.25 \mathrm{~b}$ & $0.55 \mathrm{~b}$ & $0.8 \mathrm{~b}$ & $7.5 \mathrm{~b}$ & $8.9 \mathrm{~b}$ \\
\hline N70-6-B & $0.081 \mathrm{c}$ & $0.30 \mathrm{~b}$ & $0.58 \mathrm{~b}$ & $0.5 \mathrm{~b}$ & $6.3 \mathrm{~b}$ & $7.3 \mathrm{~b}$ \\
\hline N70-8-B & $0.237 \mathrm{~b}$ & $0.13 \mathrm{~b}$ & $0.65 \mathrm{~b}$ & $0.3 \mathrm{~b}$ & $4.5 \mathrm{~b}$ & $9.8 \mathrm{~b}$ \\
\hline LSD & 0.135 & 0.35 & 0.43 & 5.6 & 15.0 & 12.7 \\
\hline Perry (nontransgenic) & $-0.011 \mathrm{f}$ & $0.60 \mathrm{a}$ & $1.25 \mathrm{a}$ & $2.8 \mathrm{a}$ & $20.0 \mathrm{a}$ & $25.8 \mathrm{a}$ \\
\hline P99-4-B & $0.153 \mathrm{de}$ & $0.58 \mathrm{a}$ & $1.10 \mathrm{a}$ & $2.8 \mathrm{a}$ & $17.8 \mathrm{a}$ & $18.8 \mathrm{a}$ \\
\hline P99-1-B & 0.091 ef & $0.43 \mathrm{a}$ & $1.03 \mathrm{a}$ & $0.5 \mathrm{~b}$ & $13.5 \mathrm{a}$ & $19.8 \mathrm{a}$ \\
\hline P53-4-B & $0.300 \mathrm{a}-\mathrm{c}$ & $0.15 \mathrm{~b}$ & $0.35 \mathrm{bc}$ & $0.5 \mathrm{~b}$ & $4.5 \mathrm{~b}$ & $7.0 \mathrm{~b}$ \\
\hline P53-30-B & $0.212 \mathrm{~b}-\mathrm{d}$ & $0.05 \mathrm{~b}$ & $0.28 \mathrm{bc}$ & $0.3 \mathrm{~b}$ & $5.0 \mathrm{~b}$ & $4.8 \mathrm{~b}$ \\
\hline P39-8-B & $0.230 \mathrm{~b}-\mathrm{d}$ & $0.13 \mathrm{~b}$ & $0.48 \mathrm{~b}$ & $0.3 \mathrm{~b}$ & $3.8 \mathrm{~b}$ & $6.8 \mathrm{~b}$ \\
\hline P53-27-B & $0.213 \mathrm{~b}-\mathrm{d}$ & $0.18 \mathrm{~b}$ & $0.50 \mathrm{~b}$ & $0.0 \mathrm{~b}$ & $3.3 \mathrm{~b}$ & $6.0 \mathrm{~b}$ \\
\hline P39-7-B & $0.320 \mathrm{ab}$ & $0.03 \mathrm{~b}$ & $0.35 \mathrm{bc}$ & $0.8 \mathrm{~b}$ & $2.3 \mathrm{~b}$ & $6.8 \mathrm{~b}$ \\
\hline P53-26-B & $0.195 \mathrm{c}-\mathrm{e}$ & $0.05 \mathrm{~b}$ & $0.13 \mathrm{c}$ & $0.0 \mathrm{~b}$ & $1.3 \mathrm{~b}$ & $2.3 \mathrm{~b}$ \\
\hline P53-28-B & $0.151 \mathrm{de}$ & $0.05 \mathrm{~b}$ & $0.10 \mathrm{c}$ & $0.0 \mathrm{~b}$ & $0.5 \mathrm{~b}$ & $2.5 \mathrm{~b}$ \\
\hline P99-2-B & $0.387 \mathrm{a}$ & $0.05 \mathrm{~b}$ & $0.13 \mathrm{c}$ & $0.0 \mathrm{~b}$ & $1.0 \mathrm{~b}$ & $1.0 \mathrm{~b}$ \\
\hline LSD & 0.109 & 0.23 & 0.35 & 1.6 & 7.6 & 7.4 \\
\hline Wilson (nontransgenic) & $-0.008 \mathrm{~d}$ & $0.83 \mathrm{bc}$ & $2.45 \mathrm{a}$ & $7.0 \mathrm{a}$ & $25.3 \mathrm{ab}$ & $31.3 \mathrm{a}$ \\
\hline W51-9-B & $-0.009 \mathrm{~d}$ & $1.30 \mathrm{a}$ & $2.48 \mathrm{a}$ & $3.0 \mathrm{~b}$ & $30.3 \mathrm{a}$ & $33.3 \mathrm{a}$ \\
\hline W59-10-B & $0.018 \mathrm{~cd}$ & $0.90 \mathrm{~b}$ & $2.15 \mathrm{a}$ & $3.0 \mathrm{~b}$ & $21.0 \mathrm{~b}$ & $29.8 \mathrm{a}$ \\
\hline W83-7-B & $0.014 \mathrm{~cd}$ & $0.55 \mathrm{~cd}$ & $2.25 \mathrm{a}$ & $2.0 \mathrm{~b}$ & $19.5 \mathrm{~b}$ & $26.3 \mathrm{a}$ \\
\hline W59-11-B & $0.153 \mathrm{~b}$ & $0.43 \mathrm{de}$ & $1.33 \mathrm{~b}$ & $2.3 \mathrm{~b}$ & $9.8 \mathrm{c}$ & $14.0 \mathrm{~b}$ \\
\hline W171-17-B & $0.235 \mathrm{a}$ & $0.13 \mathrm{e}$ & $0.55 \mathrm{c}$ & $0.3 \mathrm{~b}$ & $5.0 \mathrm{c}$ & $6.8 \mathrm{bc}$ \\
\hline W73-27-B & $0.087 \mathrm{bc}$ & $0.10 \mathrm{e}$ & $0.20 \mathrm{c}$ & $0.3 \mathrm{~b}$ & $2.5 \mathrm{c}$ & $3.8 \mathrm{c}$ \\
\hline LSD & 0.078 & 0.34 & 0.42 & 2.9 & 7.6 & 7.8 \\
\hline
\end{tabular}

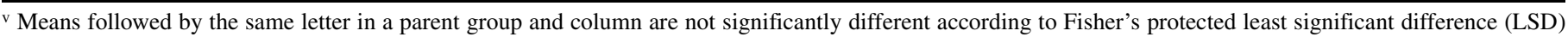
$(P=0.05)$.

${ }^{w}$ Name of transformed parent, and single-plant selection in each subsequent generation; $\mathrm{B}=$ bulked seed generation.

${ }^{x}$ Oxox determined by assay of leaflets from 10 plants/plot using a colorimetric detection method.

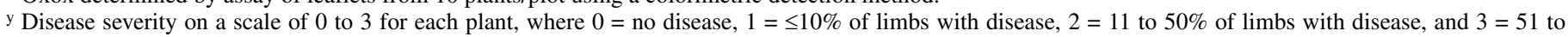
$100 \%$ of limbs with disease.

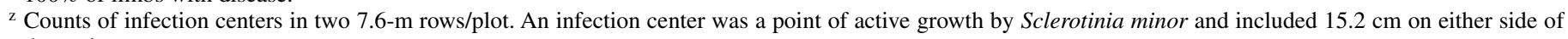
that point.
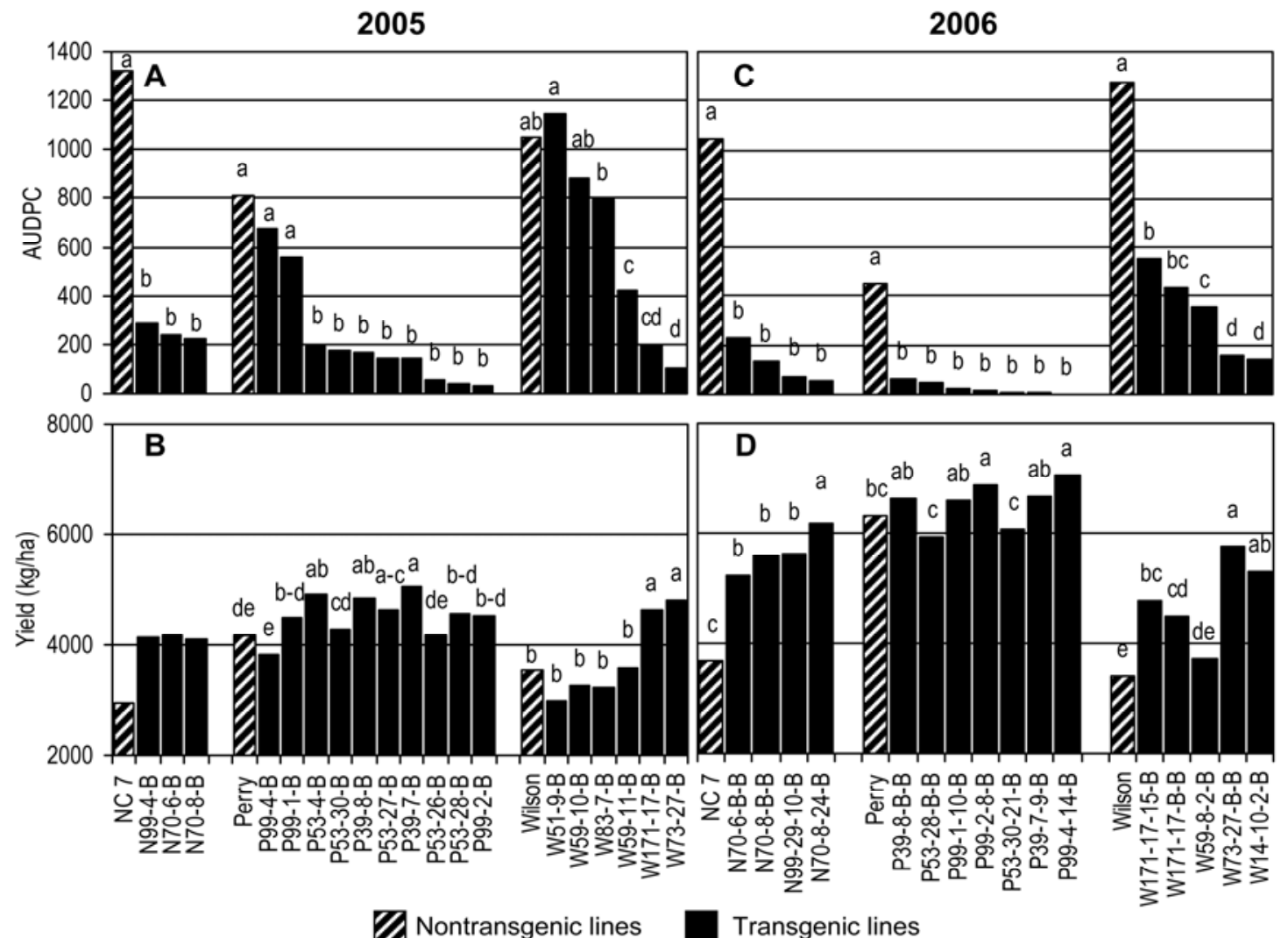

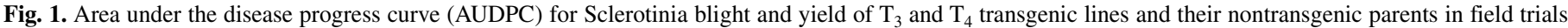

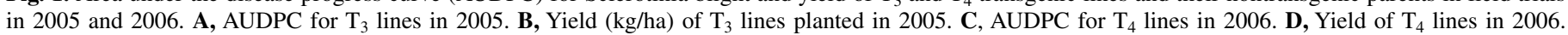
Within each cultivar group and year, bars with the same letter(s) are not significantly different according to Fisher's protected least significant difference $(P=0.05)$. 
tinia blight and reduced lesion size when leaflets were wounded and treated with $100 \mathrm{mM}$ of oxalic acid. The $\mathrm{T}_{3}$ lines had an average of 96,90 , and $74 \%$ lower disease severity compared with their corresponding nontransgenic parents NC 7, Perry, or Wilson, respectively.

In 2006, $\mathrm{T}_{4}$ seed from $22 \mathrm{~T}_{3}$ single-plant selections representing eight original transformation events were planted. All $22 \mathrm{~T}_{4}$ lines had strong oxalate oxidase gene expression $(\geq 0.065)$ (data not shown). When grouped according to the eight original transformation events, all of the $\mathrm{T}_{4}$ generation lines showed significant oxalate oxidase expression, reduced severity of Sclerotinia blight, and reduced lesion size on leaflets treated with oxalic acid (Table 1). These $\mathrm{T}_{4}$ lines had an average of 96,86 , and $89 \%$ less disease than their corresponding nontransgenic parents NC 7, Perry, or Wilson, respectively.

Trials with bulked seed. In 2005, assays of 10 arbitrarily selected plants per plot showed oxalate oxidase expression in 16 of 19 transgenic lines in the $\mathrm{T}_{3}$ generation $(\geq 0.065)$, while only 14 were significantly different from their corresponding parents (Table 2). Strong gene expression was observed in two transgenic lines of NC, nine transgenic lines of Perry, and three transgenic lines of Wilson. Nomenclature defines transformation event, single-plant selection, or bulk selection (B) in $\mathrm{T}_{0}-\mathrm{T}_{1}-\mathrm{T}_{2}$ generations, respectively. Sclerotinia blight severity was assessed for each of the 10 individual plants tested for gene expression in each plot. These ratings were significantly lower in transgenic lines compared with their nontransgenic parents, except for lines P99-1-B, P99-4-B, W51-9-B, W59-10-B, and W83-7-B, on 4 and 27 October. These lines had few to no plants with oxalate oxidase gene expression.

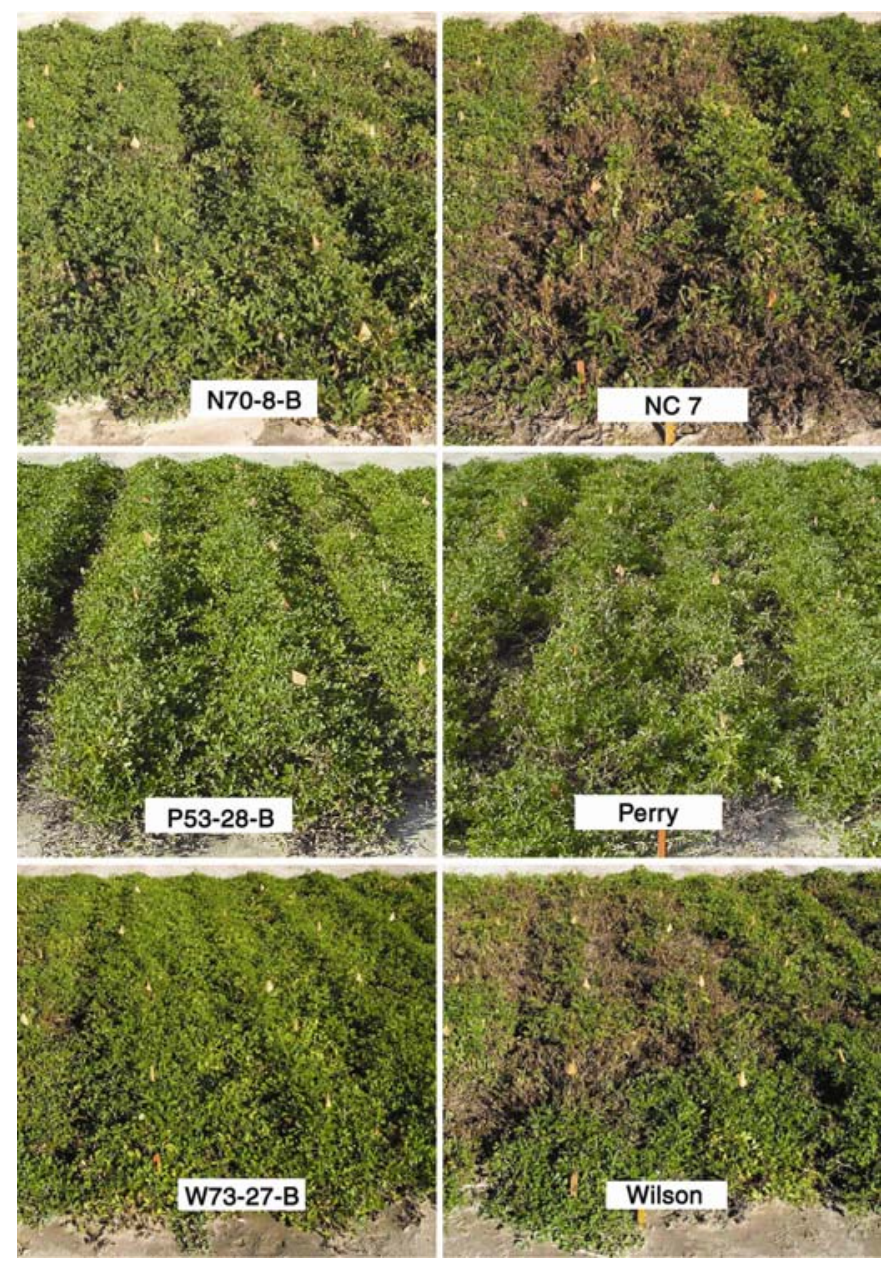

Fig. 2. Comparison of genetically modified Virginia-type peanut lines (N70-8B, P53-28-B, and W73-27-B) with resistance to Sclerotinia blight and their corresponding susceptible nontransgenic parents (NC 7, Perry, and Wilson).
Whole-plot evaluations of bulked seed lines in 2005 showed that all $\mathrm{T}_{3}$ transgenic lines had significantly lower incidence of Sclerotinia blight on 27 October (Table 2) and reduced AUDPC compared with their corresponding nontransgenic parents, except lines P99-4-B, P99-1-B, W51-9-B, W59-10-B, and W83-7-B (Fig. 1 ). The resistant transgenic lines had an average of 81,86 , and $77 \%$ less disease than their corresponding nontransgenic parents NC 7, Perry, or Wilson, respectively. This was visually evident in the field when comparing transgenic and nontransgenic plots (Fig. 2 ). All transgenic lines yielded equal to or greater than their corresponding nontransgenic parents (Fig. 1). Although the average yield of transgenic lines N99-4-B, N70-6-B, and N70-8-B was $1,200 \mathrm{~kg} / \mathrm{ha}$ greater than nontransgenic parent $\mathrm{NC} 7$, they were not significantly different, presumably due to variability in disease and possibly some segregation for the transgene in the bulked population. Transgenic lines P53-4-B, P39-8-B, P53-27-B, P39-7-B, W171-17-B, and W73-27-B had significantly higher yields of 489 to $1,261 \mathrm{~kg} / \mathrm{ha}$ greater than their corresponding nontransgenic parents (Fig. 1).

In 2006, data from 10 arbitrarily selected plants per plot confirmed oxalate oxidase gene expression $(\geq 0.065)$ in all $16 \mathrm{~T}_{4}$ transgenic lines tested (Table 3). Sclerotinia blight severity was assessed for each of the 10 individual plants tested in each plot for gene expression. Disease severity was significantly less in all $\mathrm{T}_{4}$ transgenic lines compared with their nontransgenic parents on 20 September and 9 October.

Whole-plot evaluations with bulked seed in 2006 found that all $\mathrm{T}_{4}$ transgenic lines had significantly less disease incidence on 20 September and 9 October than their nontransgenic parents (Table 3). They also showed reduced AUDPC (Fig. 1). The resistant transgenic lines had an average of 88,95 , and $74 \%$ less disease than their corresponding parents NC 7, Perry, or Wilson, respectively. Transgenic lines yielded equal to or greater than their corresponding nontransgenic parent and 10 transgenic lines (N708-24-B, N70-6-B-B, N70-8-B-B, N99-29-10-B, P99-2-8-B, P994-14-B, W14-10-2-B, W171-17-15-B, W171-17-B-B, and W7327-B-B) had significantly higher yields of 537 to $2,490 \mathrm{~kg} / \mathrm{ha}$ greater (Fig. 1).

Response to fluazinam fungicide. Treatments with fluazinam at $0.58 \mathrm{~kg}$ a.i./ha in 2007,2008 , and 2009 were designed to compare the response of transgenic lines and their nontransgenic parents to fungicide treatments $0.58 \mathrm{~kg}$ a.i./ha for control of Sclerotinia blight. Although dry weather stress in 2007 resulted in low disease intensity (19), differences in disease incidence and AUDPC between transgenic lines and their corresponding parent cultivars were significant but yields were not significantly different (data not shown).

The split-plot analysis of data for 2008 at TAREC showed significant differences $(P \leq 0.05)$ in lines (transformed and nontransformed), fungicide, and the interaction of fungicide-lines for disease incidence, AUDPC and yield. Incidence of Sclerotinia blight and AUDPC in untreated main plots was significantly lower in transgenic lines compared with nontransgenic lines in 2008 (Table 4). Fungicide treatments with fluazinam at $0.58 \mathrm{~kg}$ a.i./ha were applied twice (30 July and 2 September) and reduced AUDPC by 82,94 , and $80 \%$ in nontransgenic NC 7 , Perry, and Wilson (data not shown). Transgenic lines alone reduced AUDPC by 80,93 , and $94 \%$ compared with nontransgenic parents NC 7 , Perry, or Wilson, respectively (Table 4). Yields of transgenic lines without fluazinam were significantly higher in N70-8-24-B-B-B, P39-7-9-B-B-B, W14-10-2-B-B-B, and W73-27-B-B-B-B compared with their nontransgenic parent cultivars in 2008. No significant differences in yields of nontransgenic parent cultivars and their corresponding transgenic lines were detected in plots treated with fluazinam.

As in 2008, the split-plot analysis of data for 2009 was significant $(P \leq 0.05)$ for fungicide, cultivar, and the interaction of fungicide-cultivar. Transgenic lines showed significantly lower 
disease incidence and higher yields compared with their nontransgenic parents in main plots without fluazinam treatment (Table 5). AUDPC was reduced 98,97 , and $92 \%$ by transgenic lines without fluazinam treatment compared to their corresponding parent cultivar NC 7, Wilson, or Perry, respectively. Two applications of fluazinam (20 August and 14 September) reduced AUDPC by 57, 46, and $62 \%$ in nontransgenic cultivars NC 7, Wilson, and Perry, respectively (data not shown). Yields without the fluazinam treatment for all transgenic lines were significantly greater than their corresponding nontransgenic parent cultivars. The yields of nontransgenic cultivars and their corresponding transgenic lines were not significantly different when treated with fluazinam.

Incidence of other diseases. Occurrences of diseases other than Sclerotinia blight in field trials were low as a result of using recommended practices. Based on observations of disease incidence, Sclerotinia blight was the primary cause of disease and accounted for differences in yield. Other diseases were widely scattered and similar across transgenic lines and their nontransgenic parent in each trial and included tomato spotted wilt (Tomato spotted wilt virus), CBR (caused by Cylindrocladium parasiticum), and southern stem rot (caused by Sclerotium rolfsii). Initial laboratory studies have shown that infection by $S$. rolfsii is also limited by the oxalate oxidase gene in these peanut lines (D. E. P. Telenko, unpublished data) but, due to regulations by the United States Department of Agriculture, the transformed lines can only be planted in a limited area. Therefore, we are unable at this time to evaluate the effectiveness of this gene toward southern stem rot. Foliar diseases such as early and late leaf spot (caused

TABLE 3. Oxalate oxidase expression (Oxox), Sclerotinia blight severity, and incidence for nontransgenic parents and $16 \mathrm{~T}_{4}$ transgenic lines in $2006^{\mathrm{V}}$

\begin{tabular}{|c|c|c|c|c|c|c|}
\hline \multirow[b]{2}{*}{ Line $\left(T_{0}-T_{1}-T_{2}-T_{3}\right)^{\mathrm{w}}$} & \multirow{2}{*}{$\frac{\text { Oxox }^{\mathrm{x}}}{11 \text { September }}$} & \multicolumn{2}{|c|}{ Sclerotinia blight severity ${ }^{y}$} & \multicolumn{3}{|c|}{ Sclerotinia blight incidence ${ }^{z}$} \\
\hline & & 20 September & 9 October & 23 August & 20 September & 9 October \\
\hline NC7 (nontransgenic) & $0.026 \mathrm{~d}$ & $0.90 \mathrm{a}$ & $1.85 \mathrm{a}$ & $5.50 \mathrm{a}$ & $23.8 \mathrm{a}$ & $35.5 \mathrm{a}$ \\
\hline N70-6-B-B & $0.291 \mathrm{c}$ & $0.33 \mathrm{~b}$ & $0.73 \mathrm{~b}$ & $0.25 \mathrm{~b}$ & $6.0 \mathrm{~b}$ & $8.8 \mathrm{~b}$ \\
\hline N70-8-B-B & $0.512 \mathrm{~b}$ & $0.18 \mathrm{bc}$ & $0.38 \mathrm{bc}$ & $0.00 \mathrm{~b}$ & $2.8 \mathrm{~b}$ & $7.5 \mathrm{bc}$ \\
\hline N99-29-10-B & $0.834 \mathrm{a}$ & $0.00 \mathrm{c}$ & $0.13 \mathrm{c}$ & $0.25 \mathrm{~b}$ & $1.3 \mathrm{~b}$ & $3.5 \mathrm{bc}$ \\
\hline N70-8-24-B & $0.764 \mathrm{a}$ & $0.03 \mathrm{c}$ & $0.05 \mathrm{c}$ & $0.00 \mathrm{~b}$ & $1.5 \mathrm{~b}$ & $2.0 \mathrm{c}$ \\
\hline Perry (nontransgenic) & $0.020 \mathrm{~d}$ & $0.45 \mathrm{a}$ & $0.90 \mathrm{a}$ & 1.50 & $9.8 \mathrm{a}$ & $18.8 \mathrm{a}$ \\
\hline P39-8-B-B & $0.334 \mathrm{~b}$ & $0.03 \mathrm{~b}$ & $0.08 \mathrm{~b}$ & 0.00 & $0.8 \mathrm{~b}$ & $4.5 \mathrm{~b}$ \\
\hline P53-28-B-B & $0.194 \mathrm{c}$ & $0.03 \mathrm{~b}$ & $0.13 \mathrm{~b}$ & 0.00 & $1.0 \mathrm{~b}$ & $2.8 \mathrm{~b}$ \\
\hline P99-1-10-B & $0.561 \mathrm{a}$ & $0.03 \mathrm{~b}$ & $0.05 \mathrm{~b}$ & 0.25 & $0.3 \mathrm{~b}$ & $1.5 \mathrm{~b}$ \\
\hline P99-2-8-B & $0.579 \mathrm{a}$ & $0.00 \mathrm{~b}$ & $0.03 \mathrm{~b}$ & 0.00 & $0.0 \mathrm{~b}$ & $1.5 \mathrm{~b}$ \\
\hline P53-30-21-B & $0.195 \mathrm{c}$ & $0.00 \mathrm{~b}$ & $0.00 \mathrm{~b}$ & 0.00 & $0.0 \mathrm{~b}$ & $0.8 \mathrm{~b}$ \\
\hline P39-7-9-B & $0.590 \mathrm{a}$ & $0.00 \mathrm{~b}$ & $0.03 \mathrm{~b}$ & 0.00 & $0.0 \mathrm{~b}$ & $0.5 \mathrm{~b}$ \\
\hline P99-4-14-B & $0.528 \mathrm{a}$ & $0.00 \mathrm{~b}$ & $0.00 \mathrm{~b}$ & 0.00 & $0.0 \mathrm{~b}$ & $0.3 \mathrm{~b}$ \\
\hline Wilson (nontransgenic) & $0.019 \mathrm{~d}$ & $1.03 \mathrm{a}$ & $2.03 \mathrm{a}$ & $2.75 \mathrm{a}$ & $31.5 \mathrm{a}$ & $48.0 \mathrm{a}$ \\
\hline W171-17-15-B & $0.237 \mathrm{bc}$ & $0.40 \mathrm{~b}$ & $1.00 \mathrm{~b}$ & $0.50 \mathrm{~b}$ & $13.5 \mathrm{~b}$ & $23.5 \mathrm{~b}$ \\
\hline W171-17-B-B & $0.222 \mathrm{bc}$ & $0.25 \mathrm{bcd}$ & $0.65 \mathrm{bc}$ & $0.50 \mathrm{~b}$ & $10.5 \mathrm{~b}$ & $18.0 \mathrm{c}$ \\
\hline W59-8-2-B & $0.299 \mathrm{~b}$ & $0.33 \mathrm{bc}$ & $0.35 \mathrm{c}$ & $0.75 \mathrm{~b}$ & $9.5 \mathrm{~b}$ & $11.8 \mathrm{~d}$ \\
\hline W73-27-B-B & $0.183 \mathrm{c}$ & $0.03 \mathrm{~d}$ & $0.25 \mathrm{c}$ & $0.00 \mathrm{~b}$ & $3.0 \mathrm{c}$ & $9.5 \mathrm{~d}$ \\
\hline W14-10-2-B & $0.441 \mathrm{a}$ & $0.08 \mathrm{~cd}$ & $0.38 \mathrm{c}$ & $0.25 \mathrm{~b}$ & $2.0 \mathrm{c}$ & $9.0 \mathrm{~d}$ \\
\hline
\end{tabular}

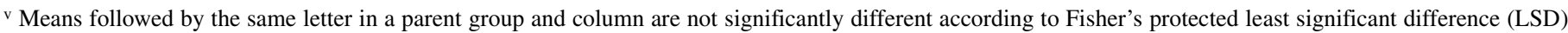
$(P=0.05)$.

${ }^{w}$ Name of transformed parent, and single-plant selection in each subsequent generation; $\mathrm{B}=$ bulked seed generation.

x Oxox determined by assay of leaflets from 10 plants/plot using a colorimetric detection method.

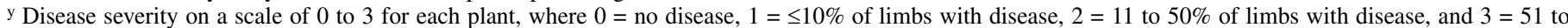
$100 \%$ of limbs with disease.

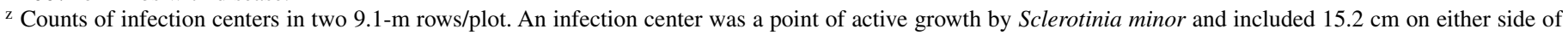
that point.

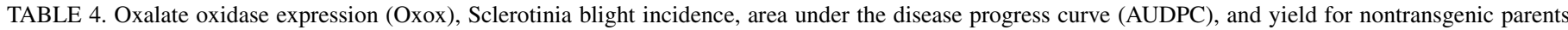
and six $\mathrm{T}_{6}$ transgenic lines in Virginia in $2008^{\mathrm{v}}$

\begin{tabular}{|c|c|c|c|c|c|c|c|c|}
\hline \multirow[b]{2}{*}{ Line $\left(T_{0}-T_{1}-T_{2}-T_{3}-T_{4}-T_{5}\right)^{\mathrm{w}}$} & \multicolumn{2}{|c|}{ Oxox $^{x}$} & \multicolumn{5}{|c|}{ Sclerotinia blight ${ }^{\mathrm{y}}$} & \multirow[b]{2}{*}{ Yield $(\mathrm{kg} / \mathrm{ha})^{\mathrm{z}}$} \\
\hline & 3 July & 4 September & 18 August & 3 September & 19 September & 7 October & AUDPC & \\
\hline NC7 (nontransgenic) & $0.009 \mathrm{c}$ & $0.012 \mathrm{c}$ & $1.3 \mathrm{a}$ & $7.3 \mathrm{a}$ & $11.5 \mathrm{a}$ & $16.8 \mathrm{a}$ & $491 \mathrm{a}$ & $4,739 \mathrm{~b}$ \\
\hline N70-8-24-B-B-B & $0.434 \mathrm{a}$ & $0.563 \mathrm{a}$ & $0.0 \mathrm{~b}$ & $0.3 \mathrm{~b}$ & $0.3 \mathrm{~b}$ & $1.0 \mathrm{~b}$ & $17 \mathrm{c}$ & $6,412 \mathrm{a}$ \\
\hline N70-6-B-B-B-B & $0.157 \mathrm{~b}$ & $0.425 \mathrm{~b}$ & $0.0 \mathrm{~b}$ & $4.5 \mathrm{~b}$ & $4.5 \mathrm{~b}$ & $5.5 \mathrm{~b}$ & $180 \mathrm{~b}$ & $5,331 \mathrm{ab}$ \\
\hline LSD & 0.067 & 0.120 & 1.0 & 2.3 & 4.5 & 5.7 & 159 & 1,138 \\
\hline Perry (nontransgenic) & $0.011 \mathrm{c}$ & $0.009 \mathrm{c}$ & $1.0 \mathrm{a}$ & $6.8 \mathrm{a}$ & $13.8 \mathrm{a}$ & $22.3 \mathrm{a}$ & $560 \mathrm{a}$ & $4,304 \mathrm{~b}$ \\
\hline P39-7-9-B-B-B & $0.322 \mathrm{a}$ & $0.458 \mathrm{a}$ & $0.0 \mathrm{~b}$ & $0.3 \mathrm{~b}$ & $1.8 \mathrm{~b}$ & $2.8 \mathrm{~b}$ & $59 \mathrm{~b}$ & $6,326 \mathrm{a}$ \\
\hline P53-30-21-B-B-B & $0.201 \mathrm{~b}$ & $0.300 \mathrm{~b}$ & $0.0 \mathrm{~b}$ & $0.3 \mathrm{~b}$ & $0.3 \mathrm{~b}$ & $0.8 \mathrm{~b}$ & $15 \mathrm{~b}$ & $5,189 \mathrm{ab}$ \\
\hline LSD & 0.090 & 0.087 & 0.8 & 1.0 & 3.4 & 4.6 & 77 & 1,479 \\
\hline Wilson (nontransgenic) & $0.014 \mathrm{c}$ & $0.013 \mathrm{c}$ & 2.3 & $7.8 \mathrm{a}$ & $12.8 \mathrm{a}$ & $18.0 \mathrm{a}$ & $545 \mathrm{a}$ & $4,332 \mathrm{~b}$ \\
\hline W14-10-2-B-B-B & $0.328 \mathrm{a}$ & $0.478 \mathrm{a}$ & 0.0 & $0.0 \mathrm{~b}$ & $0.8 \mathrm{~b}$ & $2.0 \mathrm{~b}$ & $31 \mathrm{~b}$ & $5,813 \mathrm{a}$ \\
\hline W73-27-B-B-B-B & $0.210 \mathrm{~b}$ & $0.273 \mathrm{~b}$ & 0.0 & $0.3 \mathrm{~b}$ & $2.0 \mathrm{~b}$ & $2.0 \mathrm{~b}$ & $39 \mathrm{~b}$ & $6,059 \mathrm{a}$ \\
\hline LSD & 0.058 & 0.1 & n.s. & 6.2 & 6.8 & 8.1 & 321 & 687 \\
\hline
\end{tabular}

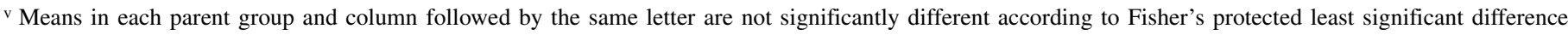
$(\mathrm{LSD})(P=0.05) ;$ n.s. $=$ not significant.

${ }^{w}$ Name of transformed parent, and single-plant selection in each subsequent generation; $\mathrm{B}=$ bulked seed generation.

x Oxox determined by assay of leaflets from 10 plants/plot using a colorimetric detection method.

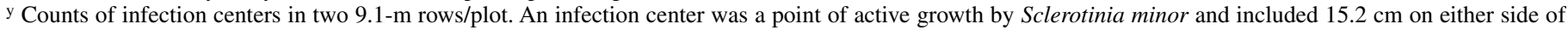
that point.

z Yields are weight of peanut with $7 \%$ moisture. 


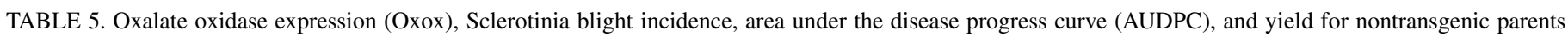
and advanced generations of six transgenic lines in Virginia in $2009^{\mathrm{v}}$

\begin{tabular}{|c|c|c|c|c|c|c|}
\hline \multirow[b]{2}{*}{ Line $\left(\mathrm{T}_{0}-\mathrm{T}_{1}-\mathrm{T}_{2}-\mathrm{T}_{3}-\mathrm{T}_{4}-\mathrm{T}_{5}-\mathrm{T}_{6-8}\right)^{\mathrm{w}}$} & \multirow{2}{*}{$\frac{\text { Oxox }^{x}}{4 \text { June }}$} & \multicolumn{4}{|c|}{ Sclerotinia blight ${ }^{\mathrm{y}}$} & \multirow[b]{2}{*}{ Yield $(\mathrm{kg} / \mathrm{A})^{\mathrm{z}}$} \\
\hline & & 24 August & 2 September & 21 October & AUDPC & \\
\hline NC7 (nontransgenic) & $0.018 \mathrm{~b}$ & 0.8 & $5.5 \mathrm{a}$ & $30.3 \mathrm{a}$ & $905 \mathrm{a}$ & $3,493 \mathrm{~b}$ \\
\hline N70-8-24-5-6-2-B-B & $0.189 \mathrm{a}$ & 0.0 & $0.0 \mathrm{~b}$ & $1.3 \mathrm{~b}$ & $31 \mathrm{~b}$ & $6,086 \mathrm{a}$ \\
\hline N70-6-B-B-48-5-9-B-B & $0.236 \mathrm{a}$ & 0.0 & $0.0 \mathrm{~b}$ & $0.0 \mathrm{~b}$ & $0 \mathrm{~b}$ & $6,409 \mathrm{a}$ \\
\hline LSD & 0.059 & n.s. & 2.4 & 11.2 & 338 & 1,251 \\
\hline Wilson (nontransgenic) & $0.015 \mathrm{c}$ & 0.3 & 2.5 & $20.8 \mathrm{a}$ & $582 \mathrm{a}$ & $4,116 b$ \\
\hline W14-10-2-27-11-B-B & $0.273 \mathrm{a}$ & 0.0 & 0.0 & $0.8 \mathrm{~b}$ & $18 \mathrm{~b}$ & $6,102 \mathrm{a}$ \\
\hline W73-25-17-34-8-2-4-B-B & $0.159 \mathrm{~b}$ & 0.0 & 0.3 & $2.8 \mathrm{~b}$ & $75 \mathrm{~b}$ & $5,737 \mathrm{a}$ \\
\hline LSD & 0.057 & n.s. & n.s. & 8.5 & 258 & 643 \\
\hline Perry (nontransgenic) & $0.021 \mathrm{~b}$ & 0.5 & $2.8 \mathrm{a}$ & $24.5 \mathrm{a}$ & $682 \mathrm{a}$ & $4,554 \mathrm{~b}$ \\
\hline P39-7-9-43-10-10-B-B & $0.391 \mathrm{a}$ & 0.0 & $0.0 \mathrm{~b}$ & $0.3 \mathrm{~b}$ & $6 \mathrm{~b}$ & $6,064 \mathrm{a}$ \\
\hline P39-7-9-1-40-B-B & $0.357 \mathrm{a}$ & 0.0 & $0.0 \mathrm{~b}$ & $1.5 \mathrm{~b}$ & $37 \mathrm{~b}$ & $6,383 \mathrm{a}$ \\
\hline LSD & 0.063 & n.s. & 2.2 & 2.4 & 86 & 659 \\
\hline
\end{tabular}

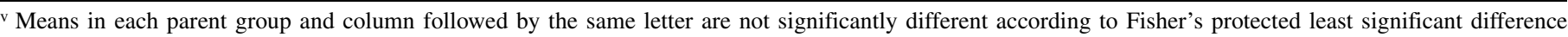
(LSD) $(P=0.05) ;$ n.s. $=$ not significant.

${ }^{w}$ Name of transformed parent, and single-plant selection in each subsequent generation; $\mathrm{B}=$ bulked seed generation.

x Oxox determined by assay of leaflets from 10 plants/plot using a colorimetric detection method.

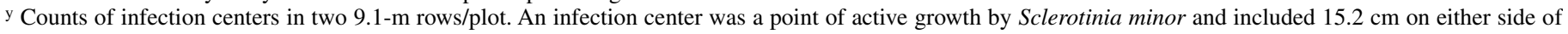
that point.

z Yields are weight of peanut with $7 \%$ moisture.

by Cercospora arachidicola and Cercosporidium personatum), and web blotch (caused by Phoma arachidicola) were controlled by four or five foliar sprays of chlorothalonil at $1.26 \mathrm{~kg}$ a.i./ha and exhibited low incidence (data not shown).

\section{DISCUSSION}

Early generations $\left(T_{2}, T_{3}\right.$, and $\left.T_{4}\right)$ of transgenic peanut lines from single-plant selections were evaluated for gene expression, resistance to Sclerotinia blight, and yield. Results verified the functionality of the oxalate oxidase gene in providing resistance to Sclerotinia blight in the field and identified superior lines with strong gene expression and disease resistance. All transgenic lines had phenotypic characteristics that were identical to their nontransgenic parents. In 2004, 21 of the 56 single-plant selections in the $\mathrm{T}_{2}$ generation of transgenic lines exhibited disease resistance when compared with their nontransgenic parent cultivars, and all advanced selections of $\mathrm{T}_{3}$ and $\mathrm{T}_{4}$ lines had reduced lesion size in bioassays of leaflets with oxalic acid as well as reduced severity of Sclerotinia blight in field trials in 2005 and 2006 (Table 1). These studies demonstrated the effectiveness of the oxalate oxidase gene in reducing levels of infection and disease caused by $S$. minor, presumably through the ability of the enzyme to degrade oxalic acid.

In all, 19 transgenic lines of the $\mathrm{T}_{3}$ generation in 2005 (Table 2) and 16 transgenic lines of the $\mathrm{T}_{4}$ generation in 2006 (Table 3) showed high oxalate oxidase expression and reduced AUDPC by 81 and $86 \%$, respectively, when compared with their nontransgenic parents. This confirmed the value of the oxalate oxidase gene in providing resistance to Sclerotinia blight. These studies corroborate reports that a wheat oxalate oxidase gene was effective in increasing resistance to $S$. sclerotiorum in transgenic soybean (3), oilseed rape (5), tomato (27), and sunflower (9) and to Septoria musiva in transgenic poplar (15). Disease resistance in transgenic peanut lines was evident at the end of the season, because the nontransgenic plots could be easily identified by more severe damage caused by Sclerotinia blight (Fig. 2).

Transgenic lines in the $\mathrm{T}_{6}$ and advanced generations showed good to excellent expression of oxalate oxidase in 2008 and 2009. As in previous years, Sclerotinia blight appeared first in nontransgenic parent cultivars and incidence was significantly lower in transgenic lines until harvest. AUDPC was significantly lower in transgenic lines compared with their nontransgenic parent cultivars, and yields were increased significantly in four of six lines tested in 2008 and all six lines in 2009. Replicated blocks of nontransgenic parent cultivars and transgenic lines treated with two applications of fluazinam at $0.58 \mathrm{~kg}$ a.i./ha for control of Sclerotinia blight showed similar disease incidence and yield in both nontransgenic and transgenic lines throughout the growing season (data not shown). Overall, the transgenic cultivars without fungicide treatments for control of Sclerotinia blight performed equally as well as nontransgenic parent cultivars with two sprays of fluazinam; therefore, by planting the transgenic lines, there was no benefit of fungicide treatments for control of Sclerotinia blight and the high fungicide input cost.

The results of these trials have demonstrated that the reduction in disease by the oxalate oxidase gene was significantly correlated with yield $(r=-0.784, P \leq 0.001$ in $2005 ; r=-0.750, P \leq 0.0001$ in 2006; $r=-0.641, P \leq 0.0001$ in 2008; and $r=-0.886, P \leq$ 0.0001 in 2009). All transgenic lines yielded better than their nontransgenic parent cultivars, with yield increases of 489 to $2,490 \mathrm{~kg} / \mathrm{ha}$ in 2004, 2005, and 2006 trials and 592 to $2,593 \mathrm{~kg} / \mathrm{ha}$ in 2008 and 2009. The increase in yield was attributed to seasonlong resistance to Sclerotinia blight, which was associated with expression of oxalate oxidase. All plant parts, including roots, limbs, leaves, flowers, pegs, and pods, are susceptible to infection by Sclerotinia minor, which can lead to losses of yield (24). We believe that the oxalate oxidase gene provides resistance to Sclerotinia blight in Virginia-type peanut by degradation of oxalic acid, which results in a reduction in disease incidence and a concomitant increase of yield.

Through use of biotechnology, transgenic peanut lines containing the novel enzyme oxalate oxidase offer an effective means for peanut producers to overcome a high risk of Sclerotinia blight in the field and increase profitability through elimination of costly fungicide sprays. This study has demonstrated that the addition of the oxalate oxidase gene, not formerly present in Virginia-type peanut, has the potential to eliminate fungicide costs for control of Sclerotinia blight, increase profits, and promote a more environmentally sound strategy for disease management.

\section{ACKNOWLEDGMENTS}

Funding was provided by the National Peanut Board, Virginia Peanut Growers' Association, Virginia Agricultural Council, and United States Department of Agriculture, Southern Region IPM Program. We thank B. Keeling, S. Byrum, E. Hobbs, and J. Hampton for technical assistance. 


\section{LITERATURE CITED}

1. Bateman, D. F., and Beer, S. V. 1965. Simultaneous production and synergistic action of oxalic acid and polygalacturonase during pathogenesis by Sclerotium rolfsii. Phytopathology 55:204-211.

2. Beute, M. K., Porter, D. M., and Hadley, B. A. 1975. Sclerotinia blight of peanut in North Carolina and Virginia and its chemical control. Plant Dis. Rep. 59:697-701.

3. Cober, E. R., Rioux, S., Rajcan, I., Donaldson, P. A., and Simmonds, D. H. 2003. Partial resistance to white mold in a transgenic soybean line. Crop Sci. 43:92-95.

4. Davidson, R. M., Reeves, P. A., Manosalva, P. M., and Leach, J. E. 2009. Germins: A diverse protein family important for crop improvement. Plant Sci. 177:499-510.

5. Dong, X., Ji, R., Guo, X., Foster, S. J., Chen, H., Dong, C., Liu, Y., Hu, Q., and Liu, S. 2008. Expressing a gene encoding wheat oxalate oxidase enhances resistance to Sclerotinia sclerotiorum in oilseed rape (Brassica napus). Planta 228:331-340.

6. Dunwell, J. M., Gibbings, J. G., Mahmood, T., and Saqlan Naqvi, S. M. 2008. Germin and germin-like proteins: Evolution, structure and function. Crit. Rev. Plant Sci. 27:342-375.

7. Godoy, G., Steadman, J. R., Dickman, M. B., and Dam, R. 1990. Use of mutants to demonstrate the role of oxalic acid in pathogenicity of Sclerotinia sclerotiorum on Phaseolus vulgaris. Physiol. Mol. Plant Pathol. 37:179-191.

8. Hollowell, J. E., and Shew, B. B. 2001. Oxalic acid production by nine isolates of Sclerotinia minor. Proc. Am. Peanut Res. Ed. Soc. 33:24.

9. Hu, X., Bidney, D. L., Yalpani. N., Duvick, J. P., Crasta, O., Folkerts, O., and Lu, G. 2008. Overexpression of a gene encoding hydrogen peroxidegenerating oxalate oxidase gene evokes defense responses in sunflower. Plant Physiol. 133:170-181.

10. Hurkman, W. J., and Tanaka, C. K. 1996. Germin gene expression is induced in wheat leaves by powdery mildew infection. Plant Physiol. 111:735-739.

11. Lane, B. G. 1994. Oxalate, germin, and the extracellular matrix of higher plants. FASEB 8:294-301.

12. Lane, B. G., Dunwell, J. M., Ray, J. A., Schmidt, M. R., and Cuming, A. C. 1993. Germin, a protein marker of early plant development, is an oxalate oxidase. J. Biol. Chem. 268:12239-12242.

13. Langston, D. B., Jr., Phipps, P. M., and Stipes, R. J. 2002. An algorithm for predicting outbreaks of Sclerotinia blight of peanut and improving the timing of fungicide sprays. Plant Dis. 86:118-126.

14. Li, J., Hegeman, C. E, Hanlon, R. W., Lacy, G. H., Denbow, D. M., and Grabau, E. A. 1997. Secretion of active recombinant phytase from soybean cell-suspension cultures. Plant Physiol. 114:1103-1111.

15. Liang, H., Maynard, C. A., Allen, R. D., and Powell, W. A. 2001. Increased Septoria musiva resistance in transgenic hybrid poplar leaves expressing a wheat oxalate oxidase gene. Plant Mol. Biol. 45:619-629.

16. Livingstone, D. M., and Birch, R. G. 1999. Efficient transformation and regeneration of diverse cultivars of peanut (Arachis hypogaea L.) by particle bombardment into embryogenic callus produced from mature seeds. Mol. Breed. 5:43-51.

17. Livingstone, D. M., Hampton, J. L., Phipps, P. M., and Grabau, E. A. 2005. Enhancing resistance to Sclerotinia minor in peanut by expressing a barley oxalate oxidase gene. Plant Physiol. 137:1354-1362.

18. Partridge, D. E., and P. M. Phipps. 2006. Susceptibility of Virginia- and runner-type cultivars of peanut to Sclerotinia blight. Biol. Cult. Tests 21:FC049.

19. Phipps, P. M. 1995. An assessment of environmental conditions preceding outbreaks of Sclerotinia blight on peanut in Virginia. Peanut Sci. 22:9093.

20. Phipps, P. M., and Partridge, D. E. 2006. Comparison of Virginia- and runner-type peanuts in strip tillage and conventional tillage. Plant Dis. Manage. Rep. 1:FC024.

21. Porter, D. M., and Beute, M. K. 1974. Sclerotinia blight of peanuts. Phytopathology 64:263-264.

22. Pundir, C. S. 1991. Purification and properties of oxalate oxidase from Sorghum leaves. Phytochemistry 30:1065-1067.

23. Shaner, G., and Finney, R. E. 1977. The effect of nitrogen fertilization on the expression of slow-mildewing resistance in Knox wheat. Phytopathology 67:1051-1056.

24. Smith, F. D., Phipps, P. M., and Stipes, R. J. 1992. Fluazinam: A new fungicide for control of Sclerotinia blight and other soilborne pathogens of peanut. Peanut Sci. 19:115-120.

25. Sturgeon, R. V. 1986. Peanut disease loss estimates for major peanut producing states in the United States for 1984 and 1985. Proc. Am. Peanut Res. Educ. Soc. 18:24-26.

26. Wadsworth, D. F. 1979. Sclerotinia blight of peanut in Oklahoma and occurrence of the sexual stage of the pathogen. Peanut Sci. 6:77-79.

27. Walz, A., Zinger-Sell, I., Loeffler, M., and Sauer, M. 2008. Expression of an oxalate oxidase gene in tomato and severity of disease caused by Botrytis cinerea and Sclerotinia sclerotiorum. Plant Pathol. 57:453-458.

28. Wei, Y., Zhang, Z., Anderson, C. H., Schmelzer, E., and Gregersen, P. L. 1998. An epidermis/papilla-specific oxalate oxidase-like protein in the defense response of barley attacked by the powdery mildew fungus. Plant Mol. Biol. 36:101-112.

29. Woo, E., Dunwell, J. M., Goodenough, P. W., Marvier, A. C., and Pickergill, R. W. 2000. Germin is a manganese containing homohexamer with oxalate oxidase and superoxide dismutase activities. Nat. Struct. Biol. 7:1036-1040.

30. Woodard, K. E., and C. E. Simpson. 1993. Characterization of growth and sclerotial production of Sclerotinia minor isolated from peanut in Texas. Plant Dis. 77:576-579.

31. Zhang, Z., Collinge, D. B., and Thordal-Christensen, H. 1995. Germinlike oxalate oxidase, a $\mathrm{H}_{2} \mathrm{O}_{2}$-producing enzyme, accumulates in barley attacked by the powdery mildew fungus. Plant J. 8:139-145.

32. Zhou, F., Zhang, Z., Gregersen, P. L., Mikkelsen, J. D., Neergaard, E. D., Collinge, D. B., and Thordal-Christensen, H. 1998. Molecular characterization of the oxalate oxidase involved in the response of barley to the powdery mildew fungus. Plant Physiol. 117:33-41. 